\title{
Kinesisk kampkunst mot gonartrose?
}

\author{
Tai chi - tradisjonell kampkunst \\ fra Kina - ga i en studie med \\ gonartrosepasienter like god \\ symptomlindring som fysioterapi.
}

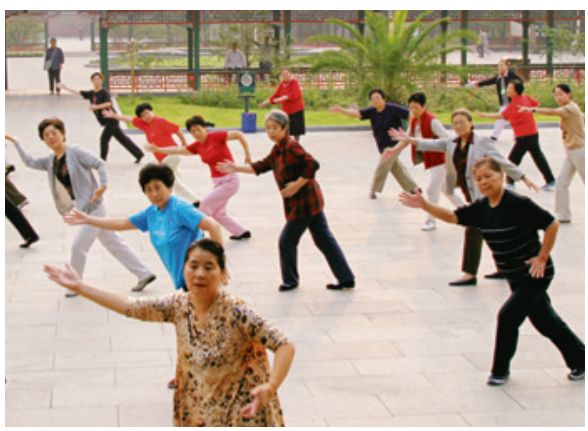

Morgentrening i Den forbudte by i Beijing - gruppen følger instruktøren i tai chi. Foto: Science Photo Library
Gonartrose er en vanlig årsak til smerter og nedsatt funksjonsevne. Tai chi, tradisjonell kinesisk kampkunst, har i tidligere studier vist noe symptomlindrende effekt.

I en studie fra USA ble mer enn 200 pasienter med gonartrose randomisert til enten tai chi eller vanlig fysioterapi to ganger i uken i 12 uker (1). I begge gruppene rapporterte pasientene signifikant bedring av både smerter og funksjonsevne, men forskjellen mellom gruppene var ikke signifikant. Tai chi hadde signifikant bedre effekt mot depresjon etter 12 uker.

- Denne studien gir oss mer kunnskap om bevegelseskonseptet tai chi, der man strukturelt og pedagogisk søker å fremme helse på både det fysiske og mentale plan, sier Liv Inger Strand, som er professor i fysioterapi ved Universitetet i Bergen. - Studien viser at skånsomme, helhetlige bevegelser som pasienter kan øve på hjemme, uten spesielt utstyr, har gode effekter. At vi får lite konkret informasjon om innholdet i fysioterapisesjonene, er en klar svakhet ved studien, sier hun.

- Innen fysioterapi er det utviklet et øvelseskonsept, «basic body awareness therapy», som er sammenlignbart med tai chi. En studie om effekter ved hofteartrose er i gang, sier Strand.

\section{Kaveh Rashidi \\ Tidsskriftet}

Litteratur

. Wang C, Schmid CH, Iversen MD et al. Comparative Effectiveness of Tai Chi Versus Physical Therapy for Knee Osteoarthritis: A Randomized Trial. Ann Intern Med 2016; 165: 77-86.

\section{Sex etter hjerteinfarkt}

\section{Hjerteinfarkt kan medføre seksuelle vansker i lang tid etter den akutte sykdomsfasen. Men det kan hjelpe å snakke med legen om problemene.}

Hjerteinfarkt kan virke inn på seksuallivet, og tidligere studier har vist at et infarkt kan føre til flere seksuelle problemer. Medikamenter kan påvirke evnen til lubrikasjon og ereksjon, men pasientene kan også være utsatt for problemer med lyst og orgasme.

I en ny studie publisert i tidsskriftet JAMA Cardiology ble data fra over 2800 spanske og amerikanske pasienter i alderen 18-55 år innlagt $\mathrm{i}$ sykehus med akutt hjerteinfarkt analysert (1). De ble fulgt i ett år. Drøyt $67 \%$ var kvinner, og median alder var 49 år. Nesten halvparten av kvinnene og rundt $60 \%$ av mennene hadde fast partner gjennom hele observasjonstiden. Av de seksuelt aktive hadde flere menn $(64 \%)$ enn kvinner $(55 \%)$ et aktivt sexliv én måned etter hjerteinfarktet. Andelene etter ett år var henholdsvis $95 \%$ og $91 \%$. Av dem som ikke rapporterte seksuelle problemer før infarktet, hadde $37 \%$ ett eller flere seksuelle problemer det påfølgende året. Hos kvinnene var manglende interesse (37\%) og mangelfull lubrikasjon (22\%) hyppigst, hos mennene var ereksjonsproblemer $(22 \%)$ og manglende interesse (19\%) det vanligste. Kun $20 \%$ av kvinnene og $30 \%$ av mennene hadde diskutert sexlivet sitt med sin lege etter innleggelsen. De som ikke hadde snakket om sex med legen etter infarktet, gjenopptok seksuell aktivitet i mindre grad enn dem som hadde hatt en slik samtale (oddsratio 1,51; $95 \% \mathrm{KI}$ 1,11-2,05).

- Dette er en stor og godt gjennomført studie som bidrar til den nokså sparsomme kunnskapen vi har om hvordan akutt og kronisk sykdom påvirker seksuallivet, sier Mette Brekke, som er fastlege og professor i allmennmedisin ved Universitetet i Oslo. Hun understreket at det er gledelig at over $90 \%$ av de seksuelt aktive pasientene hadde gjenopptatt sexlivet ett år etter infarktet. - De fleste pasientene anså det som viktig at legen tok opp spørsmål rundt seksuallivet etter hjerteinfarktet, men dessverre skjedde dette i for liten grad, sier hun.

- Vi vet fra tidligere studier at nesten alt helsepersonell synes det er viktig å snakke med pasienter om seksuallivet i relasjon til sykdom, men at de fleste likevel gjør dette i liten grad, sier Brekke. Hun mener derfor den aktuelle studien har et viktig budskap - nemlig at de fleste pasienter ønsker at legen tar opp spørsmål rundt sex. - Det er min jobb som allmennlege å møte pasientene på en lydhør måte, slik at de kan komme frem med sine spørsmål og ikke føle seg krenket ved å få trædd nedover hodet råd de ikke har bedt om, sier Brekke.

\section{Ketil Slagstad \\ Tidsskriftet}

\section{Litteratur}

1. Lindau ST, Abramsohn E, Bueno $\mathrm{H}$ et al. Sexual activity and function in the year after an acute myocardial infarction among younger women and men in the United States and Spain. JAMA Cardiol 2016. E-publisert 31.8.2016.

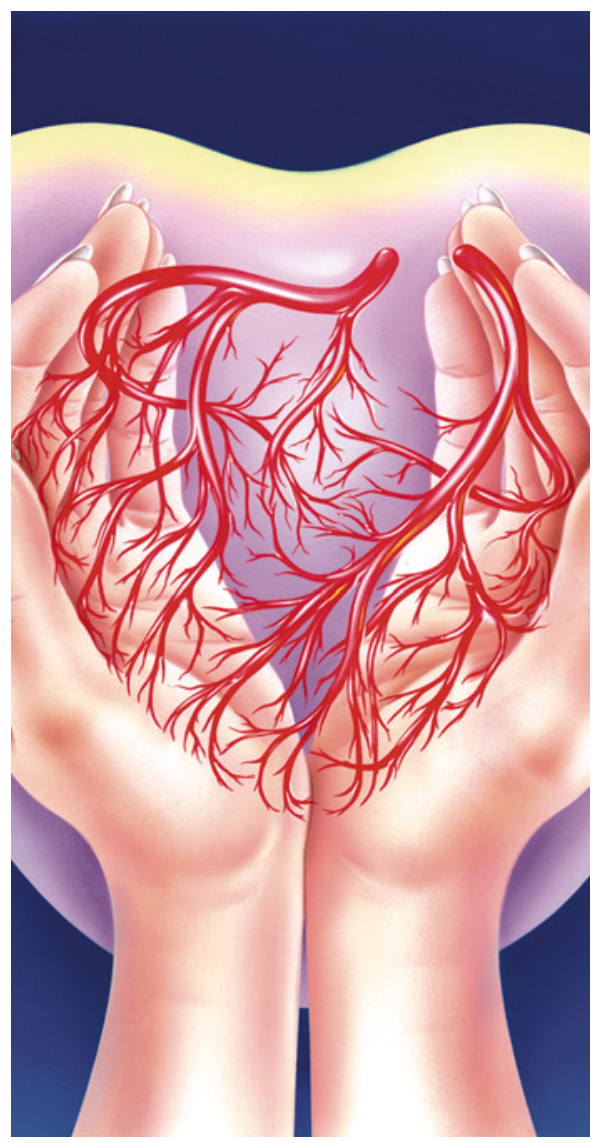

Illustrasjonsfoto: Science Photo Library 